\title{
The people's choice
}

Brenda Vale \& Robert Vale, School of Architecture, Victoria University, Wellington

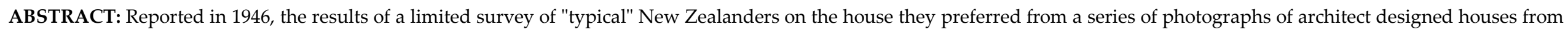

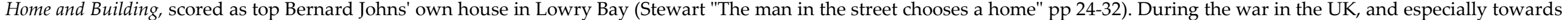

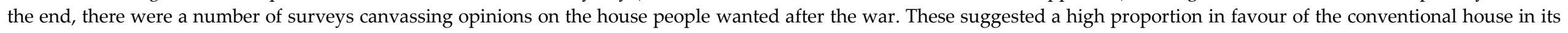

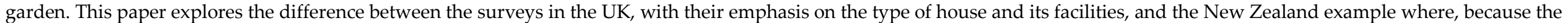

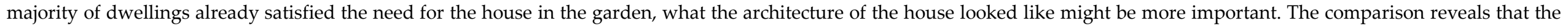
garden and open space are more important than the architecture of the house.

\section{The Social Contract}

... we are now hearing a good deal about the New Jerusalem which is to be built after the war. ${ }^{1}$

When a population is mobilised to fight for the survival of the country there is an unwritten social contract that those who return victorious will be given a better world to live in. One of the most palpable forms of this is the production of new houses that are somehow different from what went before. Swenarton describes the UK government after World War I embarking on a programme of providing a utopian ideal of healthy cottage homes in gardens. At the start of the war many of those who enlisted had been found to be in poor health and this had been linked to their bad housing conditions. This new housing programme was also initiated in

\footnotetext{
${ }^{1}$ Captain Cobb quoted, "Housing" n.p.
}

response to the threat of an army returning to a civilian life of poverty, unemployment, and bad housing and as a result turning to the revolutionary ideals of the Bolsheviks. ${ }^{2}$ An army of trained fighting men can equally fight against as for the state, as Russia had discovered. The design of these post WWI UK houses was based on the Tudor Walters Report $^{3}$ which was an investigation into the best type of house to be supplied, undertaken by a group of housing experts that included Raymond Unwin. The reporting of this famous group overshadowed a couple of contemporary reports that had issued from the relatively poor who used houses, rather than the wealthier group of society who designed them. The first was the Workmen's

\footnotetext{
2 Swenarton Homes Fit for Heroes pp 189-190.

${ }^{3}$ Local Government Boards for England and Wales and Scotland Report of Committee to Consider Questions of
} Building Construction n.p.
National Housing Council who had pressed for municipal housing improvements before the war and continued to do so in 1915. Their ideal house had at least three bedrooms and a bathroom with hot and cold running water. ${ }^{4}$ However, these demands from the users were ignored by the Local Government Board at the time. ${ }^{5}$ The second were housewives, appointed by Addison in response to a request for input into the design of houses from the Women's Labour League. Addison was a doctor, but had been a Member of Parliament since 1910 and he had been effective working for Lloyd George in the Ministry of Munitions during the war. When Lloyd George became Prime Minister after the war Addison was eventually given the task of turning the Local Government Board, with their responsibility for state subsidised

\footnotetext{
${ }^{4}$ Housing Journal p 2.

${ }^{5}$ Swenarton Homes Fit for Heroes p 91.
} 
housing, into a full Ministry of Health, which he achieved in June 1919. The group of women Addison appointed were known as the Women's Housing Sub-Committee and they reported critically on the typical house built by the Ministry of Munitions during the war and on the Local Government Board post war cottage competition. Their criticisms were never published although their recommendations did see the light of day in October 1918. ${ }^{6}$ However, the Tudor Walters Report, rather than these user surveys remained the big influence on UK housing for many years to come.

Towards the end of WWII discussion of reconstruction and what was to happen after this war was seen as a way of reminding people what they were fighting for once the immediate threat of German invasion had passed. From 1942 housing became a favourite topic for such discussions and was taken up by the Army Bureau of Current Affairs. They would supply booklets and lecturers on topics and an officer would lead the ensuing discussion. ${ }^{7}$ In his 1942-43 survey of the UK, Hodson reported on these.

${ }^{6}$ Swenarton Homes Fit for Heroes p 92.

${ }^{7}$ Army Bureau of Current Affairs Building the Post-War Home
I've attended several of these discussions in the past week ... the subject, Town Planning. In this group of twenty or thirty, we had a dozen different regiments, and different types of men. But all were united on wanting the government to control where factories must go and where houses must go-and nobody wanted to live in a flat. They wanted semi-detached and in some cases, subsidised rents that vary with income. No slums for them postwar. ${ }^{8}$

These ventures raised expectations of the type of housing to be provided postwar, while at the same time reinforcing the idea of home as being a house with a garden rather than a flat.

\section{UK surveys of postwar housing preferences}

Trying to discover what type of house people wanted after WWII was also the task of official bodies undertaking surveys, such as the study by Mass Observation. Mass Observation began in 1937 and was a social research organisation dedicated to collecting material on every day life in Britain. In surveys Mass Observation did not operate by asking direct questions but guided people to talk about their experiences and aspirations. This was necessary to avoid people only thinking the experiences they had were valid. For instance, people who lived in semi-

${ }^{8}$ Hodson Home Front p 190. detached houses would tend to say they preferred living in such houses and that these were also their ideal housing form. However, in their survey of people's housing undertaken during the war, Mass Observation found respondents were often surprised to be asked to consider whether or not they liked their home or that they could have aspirations about the sort of home they would really like. ${ }^{9}$ About $90 \%$ of those listened to in the Mass Observation study were housewives. The overwhelming thing to emerge when those asked realised they could express a preference was that they would much rather live in a house than a flat and that gardens were much desired.

There can be no doubt, however, that flats are unpopular with the great majority of English people. In the present survey, for every one person who said that she would like to live in a flat, ten said that they would like to live in a small house or bungalow. ${ }^{10}$

Even of those already living in flats only $27 \%$ wanted to keep their existing flat or live in another. ${ }^{11}$ A smaller survey of men and women in the forces produced a clearer set of desires. The following question was asked of

${ }^{9}$ Mass Observation An Enquiry in People's Homes p 53.

${ }^{10}$ Mass Observation An Enquiry in People's Homes p 46.

${ }^{11}$ Mass Observation An Enquiry in People's Homes p 220. 
2407 people.

Assume that you live in an area that has been bombed, and the whole district (including remaining houses, etc.) is to be rebuilt. You can either stay and live in a good modern flat and be near your work, or you can move to the outskirts and have a house and garden and be away from work. ${ }^{12}$

In reply an overwhelming 93\% wanted a house with a garden, 2\% wanted a flat and 5\% were undecided. The person conducting the survey stated "nearly everyone wanted the house and garden, and were willing to sacrifice quite a lot to get them."13

A survey undertaken in Scotland reached similar conclusions, despite the fact that living in a flat or tenement in the main cities of Edinburgh and Glasgow was a common experience. The report on housing after the war undertaken by the Scottish Housing Advisory Committee had specifically asked the public for their views through the press. Questionnaires were also circulated to men and women in the armed forces and in factories involved with war work. Some 15,634 people were thought to have taken

${ }^{12}$ Whittick \& Shreiner The Small House pp 202-215.

${ }^{13}$ Whittick \& Shreiner The Small House p 203.

\begin{tabular}{|c|c|c|c|c|}
\hline Occupation & Male & Female & Blue collar & White collar \\
\hline Accountant & 皮 & & & 米 \\
\hline Warehouseman & 米 & & 檏 & \\
\hline Training College Student & unknown & unknown & & (once qualified) \\
\hline P.O. Engineers' Clerk & unknown & unknown & & 碀 \\
\hline Civil Engineer & 皮 & & & 米 \\
\hline Milkman & 来 & & 来 & \\
\hline Scientific Worker & 珠 & & & 来 \\
\hline Typiste & & 楼 & & 橉 \\
\hline Optician & 畨 & & & 粠 \\
\hline Revenue Officer & 来 & & & 珠 \\
\hline Secondary School Boy & 楼 & & N/A & N/A \\
\hline Labourer & 碀 & & 檏 & \\
\hline Nurse & & 米 & & 珠 \\
\hline Radio Engineer & 米 & & & 米 \\
\hline Salesman & 米 & & & 米 \\
\hline Businessman & 棤 & & & 橉 \\
\hline Senior Secondary School Master & 皮 & & & 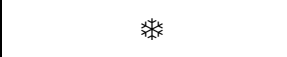 \\
\hline Government Servant & unknown & unknown & & 粠 \\
\hline Minister & 米 & & & 米 \\
\hline House wife & & 楼 & 碀 & \\
\hline
\end{tabular}


part. ${ }^{14}$ Of those who lived in town only $18 \%$ (armed forces) and 21\% (factory workers) wanted to live in either a block of flats or a flatted house. Everyone else wanted some sort of house with a garden. Ironically in the face of these results the report recommended building flats. ${ }^{15}$

When women were asked about their housing preferences at this time through women's groups taking part in consultation and questionnaires, and supposedly representing 4.5 million women in the UK, ${ }^{16} 90 \%$ wanted a house or bungalow and $99 \%$ a garden. ${ }^{17}$

The overwhelming result from these surveys was that people wanted to live in a house, with a front door and a private garden. This seems of great significance in light of the New Zealand survey of the house the people wanted undertaken by Home $\mathcal{E}$ Building magazine and discussed below. All the houses in this survey were detached and had

${ }^{14}$ Department of Health for Scotland Planning Our New Homes Appendix 3, p xix.

${ }^{15}$ Department of Health for Scotland Planning Our New Homes p 13.

16 Pleydell-Bouverie The Daily Mail Book of Post-War Homes p 15.

17 Pleydell-Bouverie The Daily Mail Book of Post-War Homes pp 19,29. gardens.

\section{The New Zealand Home \& Building Survey} In 1946 New Zealand Home $\mathcal{E}$ Building published the results of their own survey of what sort of house the "man in the street" wanted. ${ }^{18}$ Unlike the surveys in the UK described above, this article showed ten photographs of houses that had been published in the magazine and that were described as "good well-designed New Zealand architecture," to 20 people. People were selected on the basis of occupation to represent a cross section of society and are listed in the table below in the order they appeared in the article. Probable gender and grade of occupation have been added, showing the selected occupations were biased towards men and towards white collar workers. Only three people out of the 20 were obviously women.

The request was simple, to rank the ten houses in order of preference scoring 12 for the first placed, 11 for second and so on. This meant each person had 75 marks to award and the maximum possible score a house 18 Stewart "The Man in the Street Chooses a Home" pp
24-32. could receive was 240, which would only happen if every person scored it as their first choice. Only one view of each house was shown, generally a view of the front façade. All houses apart from one can be traced to articles previously published in the journal (see table below). Those asked also commented on the reasons for their preferences, though these are only randomly reported in the Home \& Building article about the survey.

The house with the highest score was the NZIA bronze medal architect's own house by Bernard Johns in Lowry Bay. This scored an amazing 218 points with 11 of the 20 voting it best and a further five giving it second place (this would give an aggregate 187 points). The table below sets out the houses in order of preference and their scores, where known. References indicate where the house was published in the journal.

Because of the scoring system the marks for all 10 houses from the 20 people asked totalled 1500. The first three houses accounted for 548 of these marks. If the remaining marks were distributed on a pro rata basis this would give 136 marks to each other house, suggesting that only the top two 
VALE \& VALE I The people's choice I AHA: Architectural History Aotearoa (2008) vol 5:93-102

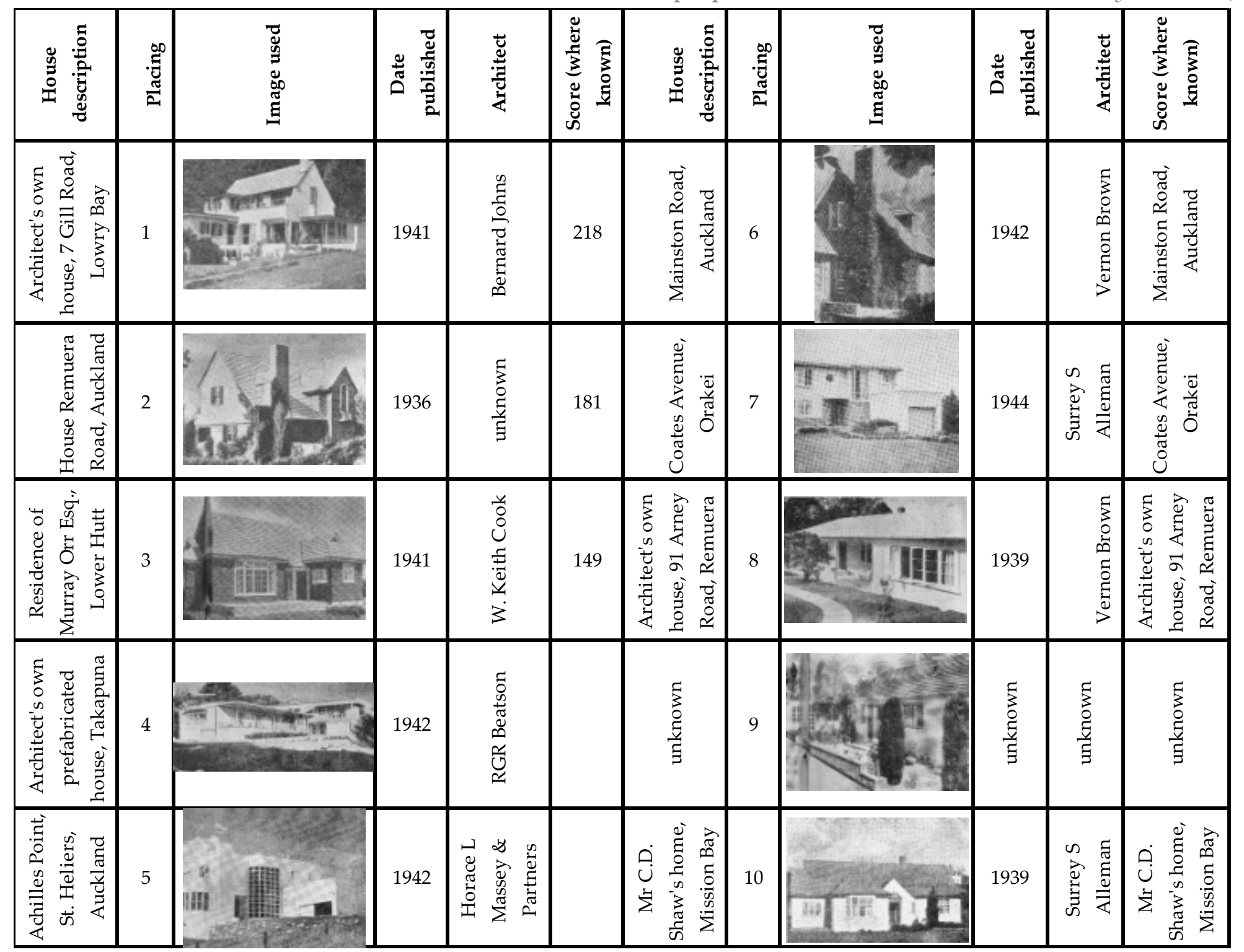

Information from: "A house at Wellington" p 15 (7 Gill Rd); "A house which makes friends with its environment" pp 12-13 (Mainston Rd); "A portfolio of modern New Zealand houses" p 25 (Remuera Rd); "The living rooms are upstairs" pp 10-11 (Orakei); "Residence of Murray Orr Esq. at Lower Hutt" pp 10-11; "The architect built himself a house among the trees" pp 12-13 (91 Arney Rd); Beatson "The shape and shadow of homes to come" p 10 (Takapuna); "A contemporary house designed for a commanding position" pp 6-7 (St. Heliers); "In the Spirit of Merrie England" p 18. (Mission Bay). 
houses had very different scores from the rest. Stewart says the remaining houses followed close behind the fourth, also suggesting there were no great disparities in their scoring, unless he was just trying to be kind. Whichever way the scores are looked at, however, the first two houses were clearly the ones the public preferred, and Bernard Johns' house a clear winner.

The winning house: the architect's own house in Lowry Bay

From the comments by Stewart in Home $\mathcal{E}$ Building this would seem to have been considered to be the wrong choice. Stewart said: "An undoubted factor in the lead in popularity of this house is the surroundings and the quality and angle of the photo." FL Griggs, the etcher, had long ago shown how a worm's eye view could enhance architecture and produce stunning architectural images, ${ }^{19}$ and the photograph of the Lowry Bay house is taken from low down on the section. However, the angle of the photograph would not seem to have been the only reason for its being liked. Two other houses in the samples are photographed from the same angle; house

19 See for instance his 1930 etching of Owlpen Manor, "Owlpen and the Cotswold Arts and Crafts movement" n.p. four, which is the partly prefabricated home of Beatson at Takapuna; and house five, a modernist essay by Horace L Massey and Partners. Like the most preferred house, all three are photographed with sunlight across the façade. In fact Stewart, rather grudgingly admits of the winning house, "these considerations apart, the majority seemed to consider the architecture of the house itself to be superior to the others." The question remains as to why this house appealed so much to these 20 , supposedly representative, people.

The winning house had been published with few details in 1941 where it was described minimally as being of concrete for the garage and foundations, with timber frame above finished with two coats of external plaster under a cream tile roof. ${ }^{20}$ What those asked in the survey liked about this house was the way the design took full advantage of the sloping site and the number of windows and balconies and the access from the house to these. Its overall irregularity was liked, although two people (the Nurse who place it ninth and the Training College Student who placed it fifth) did not like this about the

\footnotetext{
20 "A house at Wellington" p 15.
}

house. The Government Servant summed up its appeal to all as "main attraction is the ample lighting and ventilation and the abundance of outdoor accommodation provided." In fact the architectural profession also felt the house was good as it was awarded the NZIA Bronze medal in 1942, this being one of the few medals awarded during the war. The only other Bronze medal for a house in this period was given to Vernon Brown in 1940 for the Arney Road house he built for himself, ${ }^{21}$ which was placed eighth in the survey. Stewart comments on this house and its placing state: "despite its low placing, no one person had any serious objection to this house." The single storey Arney Road house by Vernon Brown was thought simple and unpretentious but despite its architectural merits was not as appealing to the average post-war Kiwi as the more complex and multi-level house by Johns. The Brown house was, "just the place to lounge around in a pair of shorts" (Civil Engineer), whereas Johns' house had a "general air of peace and restfulness" (Government Servant).

What is of more architectural interest is that, despite their Bronze medals neither house has

\footnotetext{
${ }^{21}$ Haarhoff "NZIA Awards List"
} 
any modernist traits. They have pitched roofs and outdoor covered spaces that belong as much to the typology of the villa as the modern house, although the detailing is different. An informality exists in the front façades of both houses that might only be found in the rear of the typical villa.

Modern Movement houses in the sample

There were houses that stemmed from the modern movement to choose from in the selection, so how did these fare?

The most Modern in terms of its construction approach, although that was not discussed in the survey, is Beatson's partially prefabricated own house in Takapuna. ${ }^{22}$ His prefabricated house was of timber on two levels at the front of the site with a single storey wing and sheltered terrace along its length projecting out to the rear. Beatson was co-editor of New Zealand Home \& Building at the time the survey was undertaken. In the 1942 article on his own house he stated his aim was to make a house from parts that could be mass-produced and he went as far as to set up a small factory on site to prefabricate parts such as the terrace

${ }^{22}$ Beatson "The shape and shadow of homes to come" pp 9-11. balustrade and wall panels. His module was a square, dictating the placing of glazing bars and ceiling tiles. All of this was not apparent to those asked to rank the houses based on a single photograph of the exterior. However, this house was liked, being placed fourth overall, and all thought it would get maximum sun, light and air. The projecting eaves were thought to be a good feature, though these provided covered outdoor space in a way similar to that of the Johns and Brown houses discussed above. The aesthetics of the house were what people did not like, "Too boxy with rooms strung out one after another" (Warehouseman) and "The utilitarian aspect has been over-emphasised in planning" (Training College student).

The fifth house is a version of the modernist white box by Massey and Partners, set on a dramatic site at Achilles Point. The Civil Engineer stated "The grandness of the site is equalled by the imposing design," and the Labourer thought the height of the house suited its surroundings, as did the Engineer's Clerk. Although the Revenue Officer thought the large full height window to the staircase was a good feature, all three women stated the house was over glazed. Probably they could see the impracticality of trying to clean or curtain such a massive window. The flat roof was disliked by four people (Civil Engineer, Labourer, Nurse, and Radio Engineer) and five people though it was not homely enough (Accountant, Milkman, Warehouseman, Optician, and Radio Engineer).

The other modernist house by Alleman was placed seventh. This was timber framed and clad with weather boards but still with a flat roof and large window lighting the stairs. The round window in the wall above the entry did not appeal to seven of those asked. The flat roof was again not popular and there was a feeling the garage was too high when compared to the rest of the house.

What stands out from these remarks is that it is not Modernism itself which people object to, apart from the idea of having a flat roof. What is being criticised by many are the compositional arrangements of the façade and also what the various houses might be like to live in.

\section{The house placed last}

What of the house placed last? This was one of Alleman's Mission Bay houses. ${ }^{23}$ One

${ }^{23}$ Truttman "Heritage: Garden Court Flats" n.p. 
person (Training College Student) thought it was inappropriate for New Zealand conditions. Three people, two of which were definitely men, commented adversely on the small paned Georgian style windows (Civil Engineer, Optician, and Government Servant) but otherwise there were no real adverse remarks. In some ways it is hard to see why the weatherboarded bungalow by Cook, with its Georgian small pane windows (placed third) was given a very much higher place than the Mission Bay house by Alleman. Both have a projection that shields the front door and both show glimpses of grassed garden areas immediately next to the house. The Cook house received some positive comments "Typical suburban home, not "flash" but solid," was what the Optician said while the Warehouseman thought it was "Within the average man"s range," although four people thought there were too many window panes (Engineer"s Clerk, Civil Engineer, Radio Engineer and Government Servant). What seems to be happening is that people like some houses more than others and then look for reasons to justify their particular choice. Only the Civil Engineer, who would have some design training or awareness, is more consistent in the reasons given for his selections.

\section{Other questions asked of participants}

At the end of the Home $\mathcal{E}$ Building survey six additional questions were asked of the participants and the answers given to them offer a chance for comparison with the UK post war surveys. These questions are set out in the table below.

\begin{tabular}{|l|l|}
\hline 1 & $\begin{array}{l}\text { Do you consider the view and surroundings } \\
\text { more important than the house? }\end{array}$ \\
\hline 2 & What is your preferred number of storeys? \\
\hline 3 & What is your preferred locality? \\
\hline 4 & $\begin{array}{l}\text { What are your preferred materials and } \\
\text { colour for house? }\end{array}$ \\
\hline 5 & How much ground do you want? \\
\hline 6 & $\begin{array}{l}\text { What is your preferred level of privacy } \\
\text { around the house? }\end{array}$ \\
\hline
\end{tabular}

Of the 20 people asked the first question 11 thought the view and surroundings more important than the house, with the Salesman saying, "You can improve the house but not the view." The second question dealt with the number of storeys with one being more popular than two by one vote (one person must have not given an answer). In fact the two most popular houses had two storeys, showing an inconsistency in the answers, although the survey itself was skewed as out of the ten houses six had two storeys. Apart from the bungalow by Cook, which was third, the other three single storey houses were the three placed last. The third question asked about preferred locality with most people picking the seaside, one the country, one the hills, and one the suburbs. No-one mentioned the town or city. The photographs gave the impression the houses were isolated as neighbouring houses are only clearly seen in house 10. The fourth question dealt with materials with timber frame and tiled roof the first choice, although brick with a tiled roof was close behind. A number of the houses, including the most preferred, were finished in painted render on timber frame which suggests that materials were not influencing preferences to any degree, but rather the house form and overall appearance were what those asked were judging. The fifth question is perhaps the most interesting of all. When asked how much ground they wanted "nearly all wanted about half an acre with trees, lawn, and small garden" (the latter presumably referring to a vegetable garden). The space around the house would seem to be as important as the house itself. The first placed Johns house looked as if it had plenty of space around it. The final question was about privacy where, not surprisingly people wanted to be isolated but also have neighbours. This suggests the amount of space 
around the house was thought to be critical and, in some ways, much more important than the architecture of the house.

\section{Discussion}

The big difference between the UK surveys conducted during the early 1940s and the small 1946 New Zealand survey discussed above is that the UK ones were focussed on the type of house - flat or semi-detached or bungalow - whereas the New Zealand survey was asking about architectural preferences. Much more could be gained from the New Zealand survey if it were known what sort of houses the people asked were living in. People tend not to be objective but will prefer what they already have, as Mass Observation noted in discussion of their own results.

When it comes to the architectural style preferred it is hard to draw any consistent conclusions, given the even scoring apart from the two houses placed first, which both have Arts and Crafts roots. The Modernist approach was not particularly liked or disliked. Things architects think about, such as having a large window to reflect the large internal volume containing a staircase, drew adverse criticism on practical grounds. As Stewart noted at the end of his article, the middle road was what those surveyed wanted. "Disliking the too formal artificial or striking house, most wanted homely and restful appearance in design." This is perhaps not unexpected as people emerged from the horror of WWII. Alternatively, given the general evenness of the scoring in this albeit small survey, it could be argued that architects at this time were designing the type of house the New Zealanders recognised as belonging to them and that they wanted. What is presented here in its general modesty and homeliness could be said to be the New Zealand architecture of the time.

However, what emerges from the comparison of UK surveys of the time and that of New Zealand Home $\mathcal{E}$ Building is the importance people placed on having a garden in both countries. This is a very important space to people not simply for the amenity it offers but for the symbolic division of the householder from his or her neighbour. This intermediate space offers privacy, or at least an illusion of privacy. In a low density country like New Zealand what people wanted was more outdoor space. In the UK they were just glad to have some. Architecture should remember it needs to be subservient to some of these basic desires when it comes to people choosing their preferred, or ideal, home. 


\section{REFERENCES}

"The architect built himself a house among the trees" New Zealand Home $\mathcal{E}$ Building (November 1939) IV(1):12-13.

Army Bureau of Current Affairs Building the Post-War Home London: Army Bureau of Current Affairs, 1943.

Beatson RGR, "The shape and shadow of homes to come", New Zealand Home $\mathcal{E}$ Building (December 1942) 6(2):9-11

"A contemporary house designed for a commanding position" New Zealand Home E Building (December 1942) 6(2):6-7.

Department of Health for Scotland Planning Our New Homes Edinburgh: HMSO, 1944.

Haarhoff, Errol "NZIA Awards List" University of Auckland Architecture Archive http://www.architecturearchive.auckland.ac.nz/docs/NZIA_regional_awards.pdf (viewed 29 Sept 2008)

Hodson, J.L. Home Front London: Gollancz, 1944.

"A house at Wellington" New Zealand Home $\mathcal{E}$ Building (March 1941) $\mathrm{V}(2): 15$

"A house which makes friends with its environment" New Zealand Home $\mathcal{E}$ Building (December 1942) 6(2):12-13.

Housing Journal (August 1917).

"Housing" Official Report House of Commons UK [Hansard] (4 May 1943) 389:§81-82

http://hansard.millbanksystems.com/commons/1943/may/04/housing \#S5CV0389P0-00579

"In the Spirit of Merrie England" New Zealand Home \& Building (May 1939) III(3):18

"The living rooms are upstairs" New Zealand Home E Building (Autumn 1944) 7(4):10-11.

Local Government Boards for England and Wales and Scotland Report of
Committee to Consider Questions of Building Construction with the Provision of Dwelling for the Working Classes in England and Wales and Scotland, and Report upon Methods of Securing Economy and Dispatch in the Provision of Such Dwellings London: HMSO, 1918. (CD. 9191).

Mass Observation An Enquiry in People"s Homes London: John Murray, 1943.

"Owlpen and the Cotswold Arts and Crafts movement" Owlpen Manor Estate http://www.owlpen.com/artandcraft.shtml (viewed 14 November 2008).

Pleydell-Bouverie, M. The Daily Mail Book of Post-War Homes London: Associated Newspapers, 1944.

"A portfolio of modern New Zealand houses" Building Today (Oct-Dec 1936) I(1):25.

"Residence of Murray Orr Esq. at Lower Hutt" New Zealand Home $\mathcal{E}$ Building (December 1941) V(4):10-11

Stewart, L.D. "The man in the street chooses a home" New Zealand Home $\mathcal{E}$ Building (March 1946) 9 (1):24-25,27,29,31,32.

Swenarton, M. Homes Fit for Heroes London: Heinemann Educational Books, 1981.

Truttman, Lisa J. "Heritage: Garden Court Flats, 105 Tamaki Drive, Mission Bay" Auckland City Council (20 July 2006) http://www.aucklandcity.govt.nz/council/services/heritage/pc218gar den.asp (viewed 30 September 2008).

Whittick A. \& J. Shreiner, The Small House: today and tomorrow, Crosby Lockwood, London, 1947. 